\title{
EVALUATION OF CHRONIC LOW BACK PAIN IN OSTEOPOROTIC PATIENTS IN TREATMENT WITH TERIPARATIDE
}

\author{
AVALIACÃO DA LOMBALGIA CRÔNICA NOS PACIENTES OSTEOPORÓTICOS \\ EM TRATAMENTO COM TERIPARATIDA
}

\author{
EVALUACIÓN DE LUMBALGIA CRÓNICA EN PACIENTES OSTEOPORÓTICOS \\ EN TRATAMIENTOS CON TERIPARATIDA
}

Renata Alvarenga Nunes', Jardel Pillo Alves Teixeira², Frederico Barra de Moraes², Lindomar Guimaräes Oliveira², Flávia Tandaya Grandi², Mariely Fernanda da Silva', Carlos Ney de Mesquita Júnior ${ }^{2}$

\begin{abstract}
Objective: The objective was to assess the improvement of chronic low back pain in osteoporotic patients treated with teriparatide (TPTD). Methods: This was an observational study with a convenience sample of 21 patients with osteoporosis using TPTD, 20 mcg/day, between 2006 and 2010, with chronic low back pain (more than three months). Dorsolumbar radiographs and bone densitometry (DXA) were performed before and after treatment. For pain measurement the VAS pain scale was used. Data were entered in Excel and processed in STATA/SE 8.0 with $\mathrm{Chi}^{2}$ square or Fisher ( $\left.\mathrm{p}<0.05\right)$. Results: twenty-one patients aged $40-90$ (mean 70 years), eight (40\%) had senile osteoporosis and thirteen (60\%) had osteoporosis secondary to medications. Seventeen (80\%) had previous dorsolumbar fractures. Ten (47.5\%) used TPTD for 24 months, six $(27.5 \%)$ used the medication for 18 months, four (20\%) for 12 months and one (5\%) for six months. Eight patients (40\%) received previous anti-reabsortive therapy. Thirteen patients (60\%) exhibited bone mass gain between $0 \%$ and $9 \%$ while eight (40\%), between $10 \%$ and $15 \%$. The final average VAS was 2.6 representing an improvement of $4.7(p<0.05)$. Conclusion: There was a significant reduction in the severity of low back pain with the use of TPTD (initial mean VAS: 7.3, final VAS: 2.6, improvement: 4.7).
\end{abstract}

Keywords: Low back pain; Teriparatide; Osteoporotic fractures.

\begin{abstract}
RESUMO
Objetivo: Avaliar a melhora da lombalgia crônica nos pacientes osteoporóticos em tratamento com teriparatida (TPTD). Métodos: Trata-se de um estudo observacional, com amostra por conveniência de 21 pacientes com osteoporose em uso de TPTD, 20 mcg/dia, entre 2006 e 2010, portadores de lombalgia crônica (mais de três meses). Foram realizadas radiografias dorso-lombares e densitometria óssea (DXA), antes e após o tratamento e, para a mensuração da dor, foi usada a Escala EVA. Os dados foram aplicados no Excel e as análises processadas no STATA / SE 8.0, com Qui² ou Fisher ( 0 < 0,05). Resultados: De vinte e um pacientes, com idade entre 40 e 90 anos (média 70 anos), oito deles (40\%) apresentavam osteoporose senil e treze (60\%) osteoporose secundária a medicações. Dezessete (80\%) tinham fraturas dorso-lombares prévias. Dez (47,5\%) utilizaram TPTD por 24 meses, seis (27,5\%) por 18, quatro (20\%) por 12 e um (5\%) por seis. Oito (40\%) usaram previamente antirreabsortivos. Treze pacientes (60\%) apresentaram ganho de massa óssea entre 0\% e $9 \%$ e oito (40\%), entre $10 \%$ e 15\%. A média final da EVA foi de 2,6, correspondendo a uma melhora de 4,7 ( $p<0,05)$. Conclusão: Ocorreu uma redução significativa na severidade da lombalgia com uso de TPTD (EVA inicial média: 7,3; final: 2,6; melhora: 4,7).
\end{abstract}

Descritores: Dor lombar; Teriparatida; Fraturas por osteoporose.

RESUMEN

Objetivo: Evaluar la mejoría del dolor lumbar crónico en pacientes con osteoporosis tratados con teriparatida (TPTD). Métodos: Se realizó un estudio obsenacional, con una muestra de conveniencia de 21 pacientes con osteoporosis en uso de TPTD, 20 mcg/día, entre 2006 y 2010, portadores de dolor lumbar crónico (más de tres meses). Se realizaron radiografías dorsolumbares y densitometría ósea (DXA) antes y después del tratamiento y, para la mensuración del dolor, se utilizó la Escala EVA. Los datos fueron exportados al Excel y el análisis procesado en STATA/ SE 8.0, con Qui ${ }^{2}$ o Fisher ( $\left.p<0,05\right)$. Resultado: De veintiún pacientes, con edad entre 40 y 90 años (media 70 años), ocho (40\%) presentaban osteoporosis senil y trece (60\%) osteoporosis secundaria a medicaciones. Diecisiete (80\%) tuvieron fracturas dorsolumbares previas. Diez (47,5\%) utilizaron TPTD por 24 meses, seis (27,5\%) por 18, cuatro (20\%) por 12 y uno (5\%) por seis meses. Ocho (40\%) usaron previamente antirreabsortivos. Trece pacientes (60\%) presentaron aumento de masa ósea entre 0\% y $9 \%$ y ocho (40\%), entre 10\% y $15 \%$. La media final del EVA fue de 2,6, correspondiendo a una mejora de 4,7 ( $p<0,05)$. Conclusión: Una reducción significativa en la gravedad del dolor lumbar se produjo con el uso de TPTD (EVA inicial media: 7,3; final: 2,6; mejora: 4,7).

Descriptores: Dolor de la región lumbar, Teriparatida; Fracturas osteoporóticas.

INTRODUCTION

Osteoporosis is a metabolic bone disease that is chronic, multifactorial, generally asymptomatic, and related to the progressive loss of bone mass and to fractures. It has been defined as the "Epidemic of the 21st Century", ${ }^{1}$ due to the increase in life expectancy and the aging of the world population. Concerns about the prevention, diagnosis and treatment of osteoporosis began in the 1960s and today the disease is considered a public health problem.

1. Hospital Ortopédico de Goiânia, Goiânia, GO, Brazil.

2. Hospital das Clínicas da Universidade Federal de Goiás, Goiânia, GO, Brazil.

Study conducted at the Clínica de Ortopedia e Fraturas, Goiânia, GO, Brazil.

Correspondence: Rua T-47, 369, apt.302, Ed. Piemont, Setor Bueno. 74210-180. Goiânia. GO, Brasil. realvarenga20@ hotmail.com 
Dequeker et al. ${ }^{2}$ showed vertebral fractures from osteoporosis in the radiological studies of Egyptian mummies from about 2000 B.C. In the United States, $\$ 20$ billion/year are spent on the treatments for the 1.5 million fractures attributed to osteoporosis, almost half of them $(700,000)$ located in the spine (osteoporotic vertebral compression fractures - OVCF). ${ }^{3}$ Considering the low priority given to metabolic bone diseases, it is estimated that the prevalence of osteoporosis will double by $2020 .^{4}$

Teriparatide (TPTD) is a bone tissue-forming anabolic agent derived from the molecule of the parathyroid hormone (1-34 rhPTH), and has been used in the treatment of patients with severe osteoporosis. Neer et al. ${ }^{5}$ observed that after treatment of osteoporosis with TPTD, patients had partial improvement in chronic low back pain (up to $30 \%$ ) as a secondary outcome, probably related to a decreased incidence of the OVCF. More recent studies have also demonstrated a statistically significant reduction in the frequency and severity of low back pain after treatment with TPTD. ${ }^{6-8}$

The aim of our study was to evaluate improvements in chronic low back pain in osteoporotic patients treated with teriparatide.

\section{METHODOLOGY}

In an observational study with a convenience sample, 21 patients were evaluated who had severe osteoporosis treated with teriparatide, using 20 micrograms per day, with subcutaneous administration, with at least six months and at most 24 months of medication use. The study was conducted at the Clínica de Ortopedia e Fraturas (COF) in Goiânia, GO, Brazil, in the period from 2006 to 2010.

The selected patients had chronic low back pain (over three months) with severe pain even after 90 days of medical treatment consisting of analgesics, anti-inflammatories, opioids, antiresorptive agents, calcium, vitamin D, and spinal orthoses.

Exclusion criteria were: 1) patients who required surgical treatment of the OVCF before the treatment with teriparatide was initiated, 2) or who have had to suspend teriparatide before six months of usage for any reason.

All patients were subjected to radiographs of the lower back and bone densitometry (DXA) before and after treatment with teriparatide, in the same apparatus (a Lunar DXA). To evaluate the improvement in pain, a visual analogue scale (VAS) was used at baseline and after treatment with teriparatide, with 0.0 representing no pain, and 10.0 the worst pain possible.

Teriparatide was indicated according to the criteria of Bilezikian ${ }^{9}$ from 2004: 1) a DXA with T-score < 3.0, 2) patients over 70 years, 3) multiple fragility fractures, 4) chronic use of corticosteroids, 5) no response to antiresorptive agents (fractures or low bone mass).

The database was built using Excel. Data analyses were processed in STATA/SE version 8.0. A descriptive analysis (absolute and relative frequencies) was performed to characterize the behavior of the studied variables, and the Pearson's chi-square test or Fisher's exact test was used to verify the existence of an association between them. A significance level of $5 \%$ (alpha $=0.05)$ was used in all tests, and tests with $p<0.05$ were considered to be statistically significant.

\section{RESULTS}

Twenty-one patients were evaluated, 20 women and one man, aged between 40 and 90 years (mean of 70 years), with only two smokers. (Figure 1)

Of the 21 patients, eight (40\%) had senile primary osteoporosis and 13 (60\%) had osteoporosis secondary to medications (corticosteroids or anticonvulsants for more than a year). Seventeen (80\%) had dorsolumbar fractures prior to treatment, diagnosed on radiographs, and the evolution of which was better characterized by magnetic resonance imaging (MRI) through the presence of bone edema. (Figure 2)

With respect to the period of teriparatide use, 10 (47.5\%) patients were in treatment for 24 months, six (27.5\%) for 18 months, four (20\%) for 12 months, and only one (5\%) for six months. (Figure 3 )
Of the 21 patients studied, only eight (40\%) had prior treatment with antiresorptive agents, but showed no clinical improvement. After treatment with teriparatide, 13 patients $(60 \%)$ had a bone mass gain measured by DXA between $0 \%$ and $9 \%$, whereas eight (40\%) had a gain of between $10 \%$ and $15 \%$. (Figure 4 )

With respect to pain relief, the mean initial VAS of patients was 7.3 (ranging from 5 to 9), and the final mean was 2.6 (ranging from 1 to 5), showing a significant improvement of $4.7(p<0.05)$. (Figure 5$)$

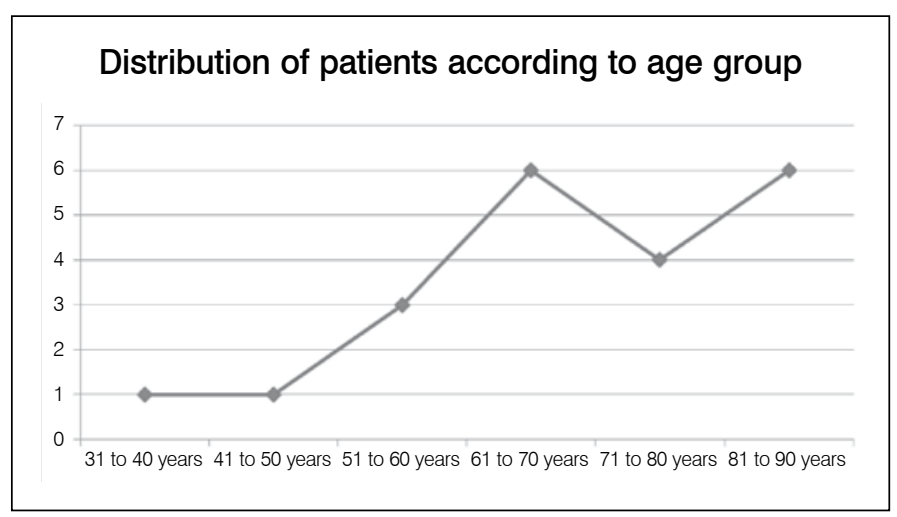

Figure 1. Distribution of patients using teriparatide according to age: higher frequency in patients over 60 years.

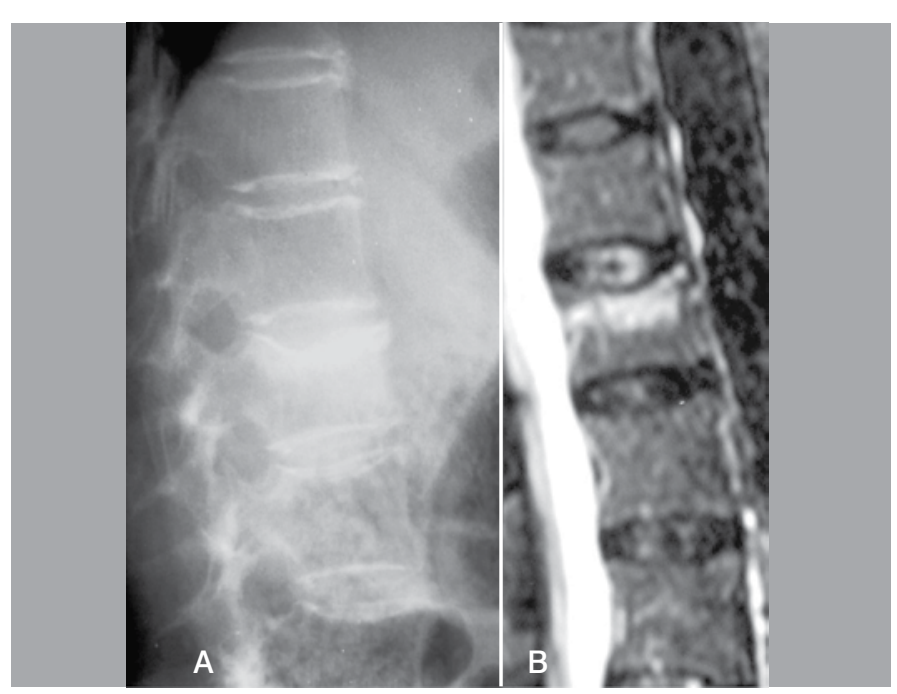

Figure 2. (A) Lateral view of the thoracolumbar spine showing compression fracture of the upper epiphyseal plate of the lumbar vertebrae L1. (B) Sagittal $\mathrm{MRI}$, a sequence that is sensitive to liquid, demonstrating hyperintense bone marrow of the L1 vertebral body suggesting acute/subacute evolution.

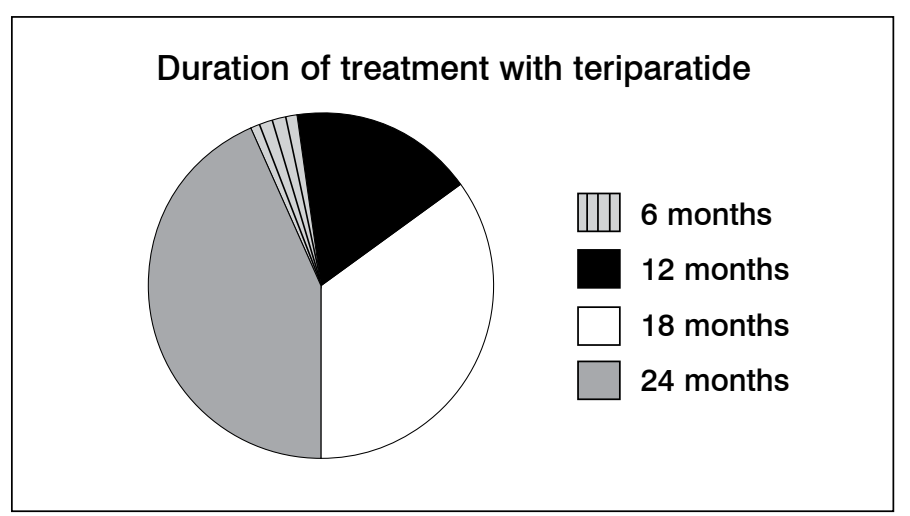

Figure 3. Duration of treatment with teriparatide: 10 (47.5\%) patients, 24 months; six (27.5\%), 18 months; four (20\%), 12 months; only one (5\%) for six months. 


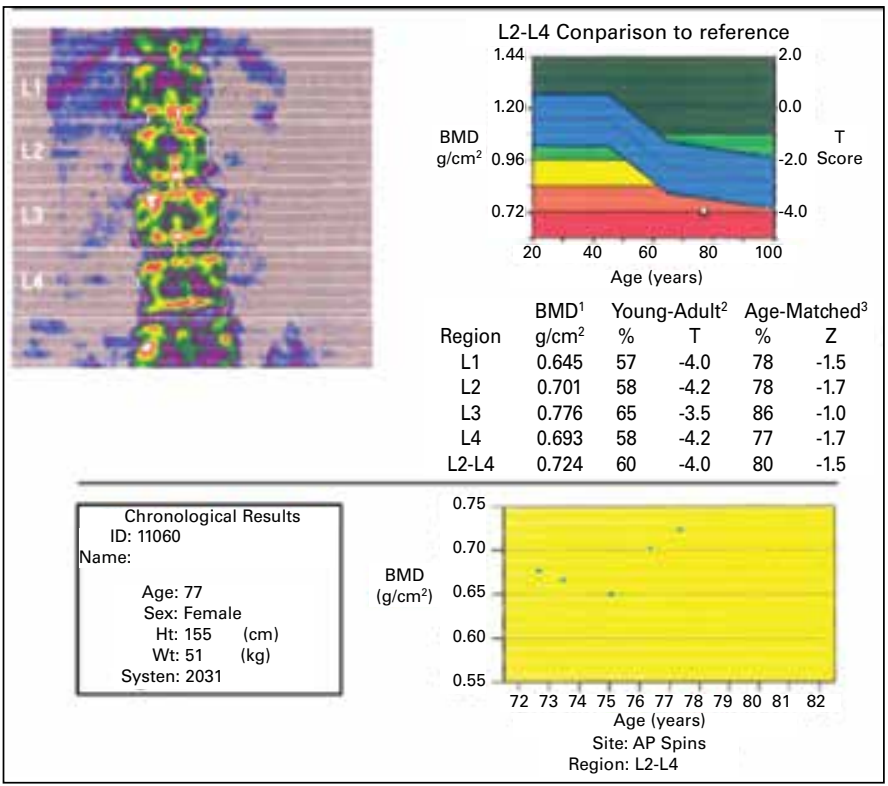

Figure 4. Bone densitometry of the lumbar spine showing a patient with severe osteoporosis who gained bone mass after treatment with teriparatide for 24 months (from 75 to 77 years).

\section{Mean visual analogue scale (VAS) of patients before and after treatment with teriparatide}

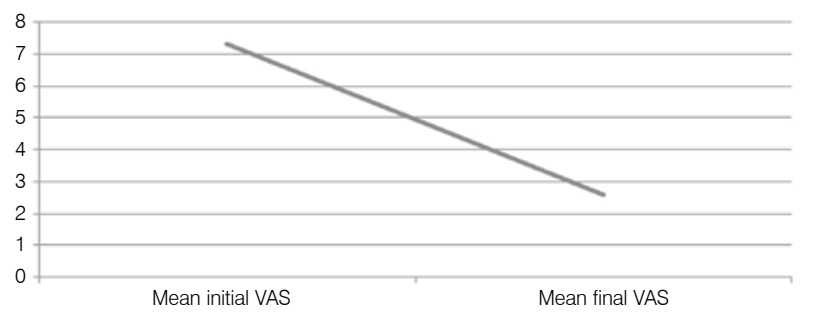

Figure 5. Demonstrating the decrease in low back pain intensity after treatment with teriparatide. The initial VAS was 7.3 and the final was 2.6. Improvement of 4.3 on the pain scale $(p<0.05)$

\section{DISCUSSION}

According to the World Health Organization (1998), osteoporosis is defined as "a disease characterized by low bone mass (resistance) and the deterioration of bone tissue microarchitecture (bone quality), increasing its frailty and thus being responsible for a higher risk of developing fractures." 10

The treatment of osteoporotic vertebral compression fractures (OVCF) is generally clinical, with analgesia, early ambulation, orthoses, and antiresorptive medication for osteoporosis. When there is failure in this type of treatment, one can opt for surgical techniques such as vertebroplasty, kyphoplasty, or arthrodesis, in order to prevent further fractures, and to decrease pain and morbidity.

Pinto et al. ${ }^{11}$ conducted a prospective study of the efficacy and duration of the analgesic effect of vertebroplasty with polymethylmethacrylate (PMMA) in patients with osteoporotic vertebral fracture. Vertebroplasty aims to increase resilience and reduce the painful symptoms of patients who do not respond to conservative treatment. In this study, $88.6 \%$ of patients had some relief of symptoms and the final result was considered good in $74.2 \%$ of cases.

Patients with OVCF frequently present with complaints of dorsal/ low back pain, which may be acute or chronic, affecting $85 \%$ of patients with radiological diagnosis of these fractures. ${ }^{12}$ Deformities are the most common cause of pain. The degree of kyphosis correlates with the quality of life of patients (motor, mental, respiratory function), mortality, and the risk of new fractures. ${ }^{13,14}$ This situation leads to sleep disorders, anxiety, depression, decreased social life, and increased dependence on other such changes. ${ }^{12}$

Nevitt et al. ${ }^{8}$ performed a meta-analysis of five studies with the objective of evaluating the effect of TPTD on low back pain in osteoporotic patients. All studies were randomized, double-blind, and matched as to the number of vertebral fractures and bone density. Four of the studies included postmenopausal women, and the other one, men with hypogonadism. Two studies were placebo-controlled, two used alendronate, and one used hormone replacement therapy. There was no heterogeneity between the studies $(p=0.60)$ nor was there a difference between groups using 20 or $40 \mathrm{mcg} /$ day of TPTD ( $p=0.64)$. There was no difference between controls (placebo or alendronate). In comparing the groups, those using TPTD had a reduced risk for low back pain of any intensity [relative risk, $0.66(95 \% \mathrm{Cl}, 0.55-0.80)]$ and moderate or severe [relative risk, $0.60(95 \% \mathrm{Cl}, 0.48-0.75)]$.

In our study, the improvement in pain was significant with TPTD, similar to the literature. The mean improvement in back pain was 4.7 for the VAS $(p<0.05)$, with a final mean of 2.6. Aloumanis et al. ${ }^{6}$ observed an improvement in the low back pain of $80 \%$ of 301 patients with mean final VAS of 2.0. Langdahl et al., ${ }^{7}$ in a study of 1,648 women, found that of the $91 \%$ of them who had already been treated with an antiresorptive agent, $72.8 \%$ completed 18 months of study and $10 \%$ of dorsal-lumbar fractures. The mean reduction in VAS was 2.6 at the end of the study $(p<0.001)$.

\section{CONCLUSION}

The study showed a statistically significant reduction in the severity of low back pain after treatment with teriparatide at a dose of $20 \mathrm{mcg} /$ day subcutaneously. With respect to pain relief, the mean initial VAS of patients, which was 7.3 (range 5-9), lowered to 2.6 (range 1-5) in the final assessment, showing an improvement of $4.7(p<0.05)$.

All authors declare no potential conflict of interest concerning this article.

\section{REFERENCES}

1. Lyritis GP, Mayasis B, Tsakalakos N, Lambropoulos A, Gazi S, Karachalios T, et al. The natural history of the osteoporotic vertebral fracture. Clin Rheumatol. 1989;8(Suppl 2):66-9.

2. Jensen ME, Evans AJ, Mathis JM, Kallmes DF, Cloft HJ, Dion JE. Percutaneous polymethylmethacrylate vertebroplasty in the treatment of osteoporotic vertebral body compression fractures: technical aspects. AJNR Am J Neuroradiol. 1997:18(10):1897-904.

3. Dequeker J, Ortner DJ, Stix Al, Cheng XG, Brys P, Boonen S. Hip fracture and osteoporosis in a Xllth Dynasty female skeleton from Lisht, upper Egypt. J Bone Miner Res. 1997;12(6):881-8.

4. NIH Consensus Development Panel on Osteoporosis Prevention, Diagnosis, and Therapy. Osteoporosis prevention, diagnosis, and therapy. JAMA. 2001:285(6):785-95.

5. Neer RM, Arnaud CD, Zanchetta JR, Prince R, Gaich GA, Reginster JY, et al. Effect of parathyroid hormone (1-34) on fractures and bone mineral density in postmenopausal women with osteoporosis. N Engl J Med. 2001;344(19):1434-41.

6. Aloumanis K, Karras D, Drossinos V, Korelis E, Polydorakis A. Fracture incidence, quality of life, and back pain during 18-months treatment with teriparatide in greek postmenopausal women with osteoporosis: Results from the European forsteo observational study. J Osteoporos. 2011;2011:510398.

7. Langdahl BL, Rajzbaum G, Jakob F, Karras D, Ljunggren O, Lems WF, et al. Reduction in fracture rate and back pain and increased quality of life in postmenopausal women

treated with teriparatide: 18-month data from the European Forsteo Observational Study (EFOS). Calcif Tissue Int. 2009;85(6):484-93

8. Nevitt MC, Chen P, Dore RK, Reginster JY, Kiel DP, Zanchetta JR, et al. Reduced risk of back pain following teriparatide treatment: a meta-analysis. Osteoporos Int. 2006:17(2):273-80.

9. Miller PD, Bilezikian JP, Deal C, Harris ST, Ci RP. Clinical use of teriparatide in the real world: initial insights. Endocr Pract. 2004;10(2):139-48

10. World Health Organization. Guidelines for preclinal evaluation and clinical trians in osteo porosis. Technical Report Series. Who: Genebra; 1998

11. Pinto $R$, Matos $R$, Neves $N$, Tulha JM, Cabral AT, Almeida L. A vertebroplastia no tratamento das fracturas vertebrais osteoporóticas dolorosas. Coluna/Columna. 2007;6(3):136-40.

12. Kado DM, Browner WS, Palermo L, Nevitt MC, Genant HK, Cummings SR. Vertebral fractures and mortality in older women: a prospective study. Study of Osteoporotic Fractures Research Group. Arch Intern Med. 1999:159(11):1215-20.

13. Lyles KW, Gold DT, Shipp KM, Pieper CF Martinez S, Mulhausen PL. Association of osteoporotic vertebral compression fractures with impaired functional status. Am J Med. 1993;94(6):595-601. 14. Oliveira LG. Osteoporose: guia para diagnóstico, prevenção e tratamento. Rio de Janeiro: Revinter; 2002 